\title{
Study on Mental Damage Compensation in "Law on Protection of Rights and Interests of Consumers"
}

\author{
Interpretation of Article 51 of the "Law on Protection of Rights and Interests of Consumers"
}

\author{
Mengkun Xu \\ China Jiliang University \\ Hangzhou, China
}

\begin{abstract}
Law on Protection of Rights and Interests of Consumers" is a modern law which inclines to protect the legitimate rights and interests of consumers based on the inferior position of consumers. Compensation for mental damages is a way to relieve the mental damages suffered by one party of the victim by means of monetary compensation. Article 51 of the "Law on Protection of Rights and Interests of Consumers" stipulates that consumers may claim compensation for mental damage from operators. From a logical point of view, it includes three parts: "operators have acts of insulting and defaming, searching the body, infringing personal freedom and infringing on the personal rights and interests of consumers or other victims"; "it causes serious mental damage"; and "victims can claim compensation for mental damage". From a structural point of view, it includes five key words such as "operators", "victims", "personal rights and interests", "serious mental damage", and "compensation for mental damage". On the basis of adhering to the holism, this paper focuses on five key words and applies semantic interpretation, historical interpretation and other interpretation methods.
\end{abstract}

Keywords-operator; victim; personal rights and interests; serious mental damage; compensation for mental damage

\section{INTRODUCTION}

As a way to compensate the victim for mental damage with money, the definition of the subject of responsibility and the determination of "seriousness" in the serious mental damage are still controversial. The amount of compensation for mental damage varies from place to place. The author analyses the application of Article 51 of the "Law on Protection of Rights and Interests of Consumers" in the past five years and summarizes the amount of compensation in judicial practice.

\section{THE SUBJECT OF COMPENSATION FOR MENTAL DAMAGE}

In Article 51 of the "Law on Protection of Rights and Interests of Consumers", the main body of compensation for mental damage includes the subject of liability and the victim. Specifically, the operator is the subject of compensation for mental damage, while the consumer and other victims are the victims of mental damage.

\section{A. Subject of Liability for Mental Damage Compensation}

Operators are the main body of liability for mental damage compensation. Article 3 of the "Law on Protection of Rights and Interests of Consumers" defines "operators". "The operators shall abide by this law when providing consumers with goods or services they produce or sell; if this law does not provide for, they shall abide by other relevant laws and regulations, but the definition of operators is still a thorny problem, such as whether the people's hospital is or not. So, how to define the operator? What obligation does the operator have to undertake compensation for mental damage? They are two issues worth discussing.

1) Definition of operator subject: The inflicter of operator's mental damage is also the subject of liability for damage compensation. To define the operator accurately is the prerequisite for the correct application of Article 51 of the "Law on Protection of Rights and Interests of Consumers". Law scholars have done more research on "consumers" and less on the definition of "operators". How to define the operator in Article 51 of the "Law on Protection of Rights and Interests of Consumers"? Does the operator here include the producer? The author believes that the main consideration is the corresponding relationship between operators and consumers. The operator in the "Law on Protection of Rights and Interests of Consumers" is a concept corresponding to the consumer. In order to clearly define the concept of "operator", it is necessary to define the concept of "consumer" in the "Law on Protection of Rights and Interests of Consumers". "Consumer" is generally defined as a social member who purchases, uses goods or receives services in order to meet the needs of life. The following points should be paid attention to when defining. First, the purpose of consumers purchasing, using goods or receiving services is to meet their needs. Are the people who "know fake and buy fake" consumers? When the Provisions on Several Questions Concerning the Application of Law in the Trial of Food and Drug Disputes were issued, the Supreme People's Court responded, "The definition of consumer prescribed by law does not exclude the consumer who knows how to buy fake goods. First, the consumer is a 
relative concept, and the consumer is relative to the producer and the seller. When trading with the producer or the operator and purchasing goods from them, they should be regarded as living consumption and their identities should be recognized as consumers unless they are also the operator. Second, it should not think that the goods purchased are not for living consumption just because he/she is subjectively aware that they are fake; thirdly, the consumers who know the fake and buy the fake are included in the protection scope of the law is to consider that it is subjectively for profit, actually has the effect of purifying the market objectively, which has a positive social significance in cracking down on unscrupulous businessmen and restraining the manufacture and sale of fake goods. "1. In addition to general living consumption, farmers can apply the "Law on Protection of Rights and Interests of Consumers" to purchase and use means of production directly used for agricultural production; secondly, consumers are members of the society who use commodities or receive services, so it is still questionable whether units (legal persons or organizations) are the protection subjects of the "Law on Protection of Rights and Interests of Consumers"; thirdly, consumption in the "Law on Protection of Rights and Interests of Consumers" should generally be paid as an article. Otherwise, the "Law on Protection of Rights and Interests of Consumers" may apply. Operators are the legal subjects who provide goods or services to consumers defined above and have consumption relations with them.

2) Obligations of operators: Chapter 3 of the "Law on Protection of Rights and Interests of Consumers" stipulates the obligations of operators, such as abiding by the law, accepting supervision and ensuring consumer safety. Here, the author mainly discusses what obligations operators should undertake to compensate for mental damage. The author believes that the obligations of consumers and other victims in Article 51 of the "Law on Protection of Rights and Interests of Consumers" include but are not limited to the following obligations: the obligations of abiding by the law, the obligations of security and the obligations of protecting consumers' personal rights as stipulated in Articles 16, 18 and 27 of the "Law on Protection of Rights and Interests of Consumers". These operators' obligations are applicable to consumers, but not to other victims. For the victims who are directly injured by the operators, the operators mainly make compensation based on the obligation of security.

\section{B. Victims of Mental Damage}

The victims of mental damage include consumers and other victims. Consumers have been discussed above. Here,

Ren Zhenyu. "The Supreme People's Court: Those who know how to buy fake are also consumers." Tecent Finance and Economics Network, February 17 , 2014 this paper mainly discusses "other victims". The author believes that "other victims" mainly include two categories: direct victims and indirect victims. The direct victim refers to the natural person other than the consumer who suffers from the operator's abuse, defamation, search of the body, violation of personal freedom and other acts which lead to mental damage. Some scholars believe that there are mainly three types of people: potential consumers, passers-by and those who have no right to enter. They believe that potential consumers and other persons who reasonably enter the business premises can claim compensation for mental damage from the operators when they meet the legal requirements. [1] Indirect victim refers to a natural person who has not been directly infringed by the operator, but whose specific close relatives have been infringed and killed by the operator's insult, defamation, search of the body, infringement of personal freedom and other acts, resulting in mental damage.

\section{PERSONAL RIGHTS AND INTERESTS}

With the continuous development of economy and society, there is a trend of expanding the scope of application of compensation for mental damage in theoretical circles, legislation and judicial practice. However, there is a longstanding basic rule that has not been broken. The compensation for mental damage should be limited by legal provisions or should be compensated under the circumstances of legal provisions. [2]

According to the current laws and regulations of China, the victims of the following kinds of cases can claim compensation for mental damage: first, victims whose intangible personality rights and interests have been infringed, especially those whose names, portraits, reputation (honor), privacy, dignity and personal freedom have been infringed; second, specific close relatives of the deceased in infringement death cases; third, the victim in infringement injury; fourth, the victim of specific kinship in the case of infringement of kinship; fifth, the victim of specific mental damage in the case of infringement of the deceased's personal interests; sixth, the victim of permanent damage to specific property. The compensation for mental damages in Article 51 of the "Law on Protection of Rights and Interests of Consumers" is mainly based on item one above, which makes more detailed provisions on the situation that operators are required to compensate for mental damages. In the way of infringement, it mainly includes insulting and defamation, searching the body, infringing personal freedom and other violations of personal rights and interests, while several infringement ways listed in the law infringe on personal dignity, personal privacy and freedom of life. He Shan, the father of "Law on Protection of Rights and Interests of Consumers", believes that the scope of application of compensation for mental damage here can't be limited to the provisions of Article 51 of "Law on Protection of Rights and Interests of Consumers", but should also be combined with Articles 1, 2 and 3 of the Interpretation of the Supreme People's Court on Several Questions Concerning the Determination of Liability for Mental Damage in Civil Tort. He believes that the following personal rights and 
interests of consumers can be infringed upon to claim compensation for mental damage: first, infringement on the material personality rights of consumers, such as the right to life, health and body; second, infringement on the spiritual personality rights of consumers, such as the right to name, portrait, reputation and privacy; and third, infringement on the personal dignity and personal freedom of consumers. [3]

\section{Serious Mental Damage AND CORRESPONDING COMPENSATION}

At present, the laws and regulations stipulating "compensation for mental damage" restrict the "seriousness" of mental damage. For example, "compensation for serious mental damage" is used in Article 51 of the "Law on Protection of Rights and Interests of Consumers" and Article 22 of the "Tort Liability Law", and the "Interpretation of the Supreme People's Court on Several Issues Concerning the Determination of Liability for Compensation for Mental Damage in Civil Tort" is limited by the statement that "mental damage caused by infringement leads to serious consequences". Article 35 of the "State Compensation Law" stipulates that if serious consequences are caused, the corresponding solace money for mental damage shall be paid. So what is serious mental damage? Why compensate only for "serious" mental damage? How to judge the "seriousness"?

\section{A. Serious Mental Damage}

Some scholars believe that under the current law, the "seriousness" of mental damage should be interpreted as "the rule of non-compensation for minor damage". [4] $\mathrm{He}$ believes that the reasons lie in the following two points: firstly, from the perspective of law and economics, when the mental damage is small enough to make the infringer bear the responsibility, the benefits obtained are less than the administrative cost estimated by the loss, and the compensation for mental damage should be negated exceptionally. Second, it is based on the practice of German law. In the second amendment of German Law on Damage Compensation, there was a clause on the limitation of compensation for solace claim. Although the Law Committee failed to adopt this clause, the views and judicial practice of some German scholars limited the compensation for minor damages. However, minor mental damage can be remedied by requiring the infringer to "stop infringing, restore his reputation, eliminate influence and apologize".

Although the "rule of non-compensation for minor damage" has its rationality, in practice, how to judge the "severity" of mental damage is a thorny problem. Some scholars believe that it should be judged on the basis of "the extent of the inflicter's fault, the specific circumstances of the infringement act and other factors"; [5] Some scholars also believe that the "serious consequences" should be interpreted with an expanded purpose, and that the infringer's infringement plot, subjective fault, mental distress, and the close degree of causation should be considered comprehensively, so that the judge can use his discretion to make recognition. [6] Professor Zhang Xinbao believes that there are three main ways to confirm "serious mental damage": first is to confirm mental damage according to the extreme external manifestations of mental distress such as mental illness and suicide and self-injury; second is to confirm mental damage according to the serious situation of the results of non-property damage such as personal disability and reputation damage; third is to confirm mental damage according to the subjective mentality, the seriousness and other infringement circumstances. At the same time, Professor Zhang pointed out that when judging the extent of the victim's mental damage, the acts of the victim, the non-property damage of the victim (besides the mental damage) and the extreme manifestations of the victim's mental damage often need to be combined to make a comprehensive judgment. [7] It is precisely on the basis of serious mental damage that judges are given great discretion. In order to promote the unification of judicial decisions, many local courts have issued some internal guidance on the judgment of the severity of mental damage, such as "Opinions of Shandong Provincial Superior People's Court on Several Questions Concerning the Trial of Personal Damage Compensation Cases" ${ }^{2}$, and "Opinions of Fujian Provincial Superior People's Court on Several Questions Concerning the Trial of Personal Damage Compensation Cases" $^{3}$. This also causes the inconsistency of judicial decisions in different areas of compensation for mental damage.

\section{B. Compensation for Mental Damage}

1) Recognition of the amount of mental damage compensation: When the "Law on Protection of Rights and Interests of Consumers" (Draft) of 2013 solicited opinions from the society, some places suggested that the calculation criteria and limits of compensation for mental damage should be clarified. [8] However, the final article 51 of the "Law on Protection of Rights and Interests of Consumers" does not specify the criteria for determining the amount of compensation for mental damage. In judicial practice, it can be determined according to Article 10 of the Interpretation of the Supreme People's Court on Several Questions Concerning the Determination of Compensation Liability for Mental Damage in Civil Tort in light of the specific conditions of consumers and other victims. The following factors should be taken into account: the degree of fault of the infringer, excepting as otherwise stipulated by law; the specific circumstances of the infringement, such as means, occasions and modes of conduct; the consequences of the infringement act; the profit situation of the infringer; the economic capacity of the infringer to assume responsibility;

2 Article 86: If the victim's normal work, life and study are affected by the violation, it is a general mental damage; if the victim's violation results in serious consequences such as work failure, decline in academic performance, inconsistency in life or suicide, it is a serious damage.

Paragraph 2 of Article 24: If a victim's appearance is harmed, resulting in adverse consequences or impaired human function, or if it does not cause damage to his appearance or human function, but it does cause lasting and profound mental suffering to the victim, the victim's claim for compensation for mental damage shall be supported. 
the average living standard of the area that the court of appeal is located.

2) Juridical practice: Searching legal documents online in China's judicial documents, the limited date of judgment is from March 15, 2014 to December 20, 2018. By searching the keywords Article 51 of "Law on Protection of Rights and Interests of Consumers" and "Consumer Mental Damage", a total of six results were retrieved. The specific judgments are as the following:

TABLE I. JUdicial APPLICATION OF ARTIClE 51 OF THE "LAW ON PROTECTION OF RightS AND INTERESTS OF CONSUMERS"

\begin{tabular}{|c|c|c|c|c|c|}
\hline Case code & $\begin{array}{c}\text { Cause of } \\
\text { action }\end{array}$ & $\begin{array}{l}\text { Does it } \\
\text { compensate for } \\
\text { mental loss }\end{array}$ & $\begin{array}{l}\text { Is it applied to } \\
\text { article of "Law on } \\
\text { Protection of } \\
\text { Rights and } \\
\text { Interests of } \\
\text { Consumers" } \\
\end{array}$ & Judgment reason & Judgment court \\
\hline $\begin{array}{lll}\text { No. } & 1334 & \text { of } \\
\text { First } & \text { Trial } & \text { of } \\
\text { Civil } & \text { Court } & \text { of } \\
\text { Yinzhou District } \\
\text { of Ningbo } & \text { City } \\
(2015)\end{array}$ & \begin{tabular}{|lr} 
Disputes & over \\
contracts & of \\
carriage & of \\
passengers &
\end{tabular} & No & No & $\begin{array}{l}\text { The court refused to support the accuser's choice of } \\
\text { claiming his rights from the contractual relationship, } \\
\text { and there was no such case in this case as listed in } \\
\text { Article } 51 \text { of the "Law on Protection of Rights and } \\
\text { Interests of Consumers". }\end{array}$ & $\begin{array}{l}\text { People's Court of Yinzhou } \\
\text { District of Ningbo City }\end{array}$ \\
\hline $\begin{array}{l}\text { No. } 10 \text { of Final } \\
\text { Judgment of } \\
\text { Intermediate } \\
\text { People's Court } \\
\text { of Haikou City, } \\
\text { Hainan Province } \\
(2015)\end{array}$ & $\begin{array}{l}\text { Sales } \\
\text { Contract } \\
\text { Dispute }\end{array}$ & No & No & $\begin{array}{l}\text { There is no evidence to prove that the staff members } \\
\text { of the defendant have insulted, abused and intimidated } \\
\text { him. }\end{array}$ & $\begin{array}{l}\text { Intermediate People's } \\
\text { Court of Haikou City, } \\
\text { Hainan Province }\end{array}$ \\
\hline $\begin{array}{l}\text { No. } 154 \text { of First } \\
\text { Trial of Civil } \\
\text { Court r of } \\
\text { Yinzhou District } \\
\text { of Ningbo City } \\
(2015)\end{array}$ & \begin{tabular}{|lr|}
\multicolumn{2}{|l|}{ Disputes over } \\
contracts of \\
carriage & of \\
passengers &
\end{tabular} & No & No & $\begin{array}{l}\text { The court refused to support the accuser's choice of } \\
\text { claiming his rights from the contractual relationship, } \\
\text { and there was no such case in this case as listed in } \\
\text { Article } 51 \text { of the "Law on Protection of Rights and } \\
\text { Interests of Consumers". } \\
\text { There is the situation listed in Article } 51 \text { of the "Law } \\
\text { on Protection of Rights and Interests of Consumers", } \\
\text { and the court refused to support it. }\end{array}$ & $\begin{array}{l}\text { People's Court of Yinzhou } \\
\text { District of Ningbo City }\end{array}$ \\
\hline 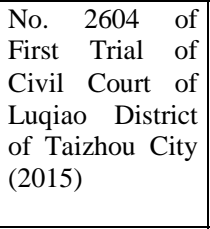 & \begin{tabular}{ll|} 
Dispute of \\
Product \\
Liability
\end{tabular} & Yes & No & $\begin{array}{l}\text { Article } 51 \text { of the "Law on Protection of Rights and } \\
\text { Interests of Consumers" doesn't specify the mental } \\
\text { damage compensation obligation of producer. } \\
\text { According to article } 22 \text { of Tort Liability Law and } \\
\text { article } 1 \text { of Interpretation of Supreme People's Court } \\
\text { on Several Issues Concerning the Determination of } \\
\text { Liability for Compensation for Mental Damage }\end{array}$ & $\begin{array}{l}\text { People's Court of Luqiao } \\
\text { District of Taizhou City, } \\
\text { Zhejiang Province }\end{array}$ \\
\hline $\begin{array}{lll}\text { No. } & 7043 & \text { of } \\
\text { First } & \text { Trial } & \text { of } \\
\text { Civil } & \text { Court } & \text { of } \\
\text { Xicheng } & \text { District } \\
\text { of } & \text { Beijing } & \text { City } \\
(2014) & \end{array}$ & $\begin{array}{l}\text { contract } \\
\text { disputes of } \\
\text { urban public } \\
\text { transport }\end{array}$ & No & No & $\begin{array}{l}\text { This case is a dispute of urban public transport } \\
\text { contract. There is no legal basis for the plaintiff to } \\
\text { compensate the defendant. The court refused to } \\
\text { support it. }\end{array}$ & $\begin{array}{l}\text { People's Court of Xicheng } \\
\text { District of Beijing City }\end{array}$ \\
\hline $\begin{array}{lrr}\text { No. } & 00365 & \text { of } \\
\text { First } & \text { Trial } & \text { of } \\
\text { Civil } & \text { Court } & \text { of } \\
\text { Xiacheng } & \\
\text { District } & \text { of } \\
\text { Hangzhou } & \text { City } \\
(2015) & \end{array}$ & $\begin{array}{l}\text { Tracel } \\
\text { Contract } \\
\text { Dispute }\end{array}$ & Yes & Yes & $\begin{array}{l}\text { According to item } 2 \text { of article } 8 \text {, and article } 10 \text { of the } \\
\text { "Interpretation of the Supreme People's Court on } \\
\text { Several Issues Concerning the Determination of } \\
\text { Compensation Liability for Mental Damage" and } \\
\text { article } 51 \text { of "Law on Protection of Rights and } \\
\text { Interests of Consumers" }\end{array}$ & $\begin{array}{lll}\text { People's } \quad \text { Court } & \text { of } \\
\text { Xiacheng } \quad \text { District } & \text { of } \\
\text { Hangzhou City } & \end{array}$ \\
\hline
\end{tabular}

Based on the retrieval results of Chinese judicial documents and the data in "Table I", the following conclusions can be drawn. Firstly, there are fewer cases involving "compensation for consumer's mental damage" in judicial practice in China (hereinafter referred to as the victims of Article 51 of the "Law on Protection of Rights and Interests of Consumers", including consumers and other victims, such as consumers and other victims). Secondly, the success rate of applying for compensation for mental damage according to Article 51 of the "Law on Protection of Rights and Interests of Consumers" is not high. According to Article 51 of the "Law on Protection of Rights and Interests of
Consumers", only about one-third of the cases have been awarded compensation for mental damage, while only half of these cases (cases published by China Judicial Documents Network up to now) have been awarded compensation for mental damage according to Article 51 of the "Law on Protection of Rights and Interests of Consumers". Thirdly, the main reasons for the failure to award compensation for mental damage according to the "Law on Protection of Rights and Interests of Consumers" are as follows: first, the parties choose to claim their rights from the contractual relationship and there are no cases listed in Article 51 of the "Law on Protection of Rights and Interests of Consumers"; 
second, the parties have not provided evidence or sufficient evidence for mental damage.

\section{FURTHER CONSIDERATION ON CONSUMER'S MENTAL DAMAGE COMPENSATION}

\section{A. "Balance" Between Consumer's Rights and Operator's Rights}

The "Law on Protection of Rights and Interests of Consumers", based on the asymmetry of economic status between consumers and operators, especially information, favors the protection of consumers. This is one of the signs of the development of the rule of law and social progress. However, it is necessary to note that the protection of consumers' rights and interests needs to be limited. The best result of the preferential protection of consumers is the "balance" between consumers' rights and operators' rights. First, consumers should not abuse their rights to infringe on the legitimate rights of operators. Article 3 of the General Principles of Civil Law stipulates that "the personal rights, property rights and other legitimate rights and interests of civil subjects shall be protected by law, and no organization or individual may infringe upon them." Consumers should exercise their rights within the framework of the law. Secondly, operators have the right to operate, and they have the right to choose their own ways and methods which are beneficial to their operation on the basis of legitimacy. For this reason, some scholars cited a typical case: if the operators refuse customers to enter on the grounds of irregular clothes, shall they bear the compensation for mental damage? [9] For this case, the first view is that the defendant make the personal discrimination against the plaintiff, which is an insult to the plaintiff, and should compensate for the plaintiff's moral damage; the second view is that the defendant has the right to make decisions independently, and it has the right not to allow the plaintiff who is not well dressed to enter, and there is no legal basis for the plaintiff to claim compensation for moral damage. Some scholars pointed out that the defendant only restricts those consumers who are not well dressed and have uncivilized behavior to enter their business places from the point of view of common people's understanding. The defendant does not restrict the consumption rights and interests of ordinary consumers, nor does it aim at specific subjects, which does not infringe on the personal dignity of consumers, and does not constitute a liability for compensation for mental damage. [9]

\section{B. Proposal to Unify and Clarify the Criteria for the Determination of Serious Mental Damage}

At present, there is no unified criterion for the determination of serious mental damage in China. Some local governments have issued a series of guidance for the convenience of court decisions, which objectively promotes the local judicial decisions on mental damage compensation. However, this also results in the inconsistency of the national judicial decisions on mental damage compensation. The author believes that the main reasons for unifying and defining the criteria for the identification of serious mental damage are as follows: first is the immeasurability of mental damage. Mental damage is different from property damage. If the consumer's mental damage does not meet certain medical standards (e.g., disability), it is difficult to measure the loss scientifically. Especially, the law of China limits the severity of mental damage compensation, which puts forward higher requirements for defining the standard of mental damage determination. Second is the individual difference of consumers. The same infringement may cause different degrees of mental damage to different consumers, which is one of the difficulties in identifying mental damage. Thirdly, in judicial practice, judges make decisions based on discretion or local guidance, which is not conducive to the unification of judicial decisions in China. The unification and clarification of the criteria for the determination of serious mental damage will help to better protect the legitimate rights and interests of consumers and operators, promote the "balance" between the rights and interests of consumers and operators, and also promote the construction of a society ruled by law, and promote the development of market economy and social progress.

\section{CONCLUSION}

China has not yet unified the criteria for the determination of serious mental damage. Although some local judicial decisions on compensation for mental damage have been promoted objectively in order to facilitate the judicial adjudication, it also causes the situation of the national judicial decisions on compensation for mental damage. At this stage, it is necessary to unify and clarify the criteria for identifying serious mental damage, which will not only promote the construction of a society ruled by law, but also promote the development of market economy and social progress.

\section{REFERENCES}

[1] Peng Xianglong. Research on Compensation for Consumers' Mental Damage - Comment on Article 51 of the "Law on Protection of Rights and Interests of Consumers" [D]. China Youth University of Political Studies, 2016. (in Chinese)

[2] Zhang Xinbao. Research on Compensation System for Mental Damage [M]. Beijing: Law Press, 2012. (in Chinese)

[3] He Shan. Interpretation and Practical Guide to the "Law on Protection of Rights and Interests of Consumers" of the People's Republic of China [M]. Beijing: China Democracy and Legal Publishing House, 2013. (in Chinese)

[4] Ye Jinqiang. Interpretative framework of the compensation system for mental damage [J]. Jurist, 2011 (5). (in Chinese)

[5] Hu Ping. Research on Compensation System for Mental Damage [M] Beijing: China University of Political Science and Law Press, 2003. (in Chinese)

[6] Yang Lixin (editor-in-chief). Research on Compensation for Menta Damage, a controversial issue of civil and commercial law theory [M] Beijing: Renmin University of China Press, 2004. (in Chinese)

[7] Zhang Xinbao. Study on the System of Compensation for Menta Damage [M]. Beijing: Law Press, 2012. (in Chinese)

[8] Civil Law Office of the Law and Industry Committee of the Nationa People's Congress. Legislative Background and Views of "Law on Protection of Rights and Interests of Consumers" [M]. Beijing: Law Press, 2013. (in Chinese)

[9] Liu Yumin. Mental Damage Compensation [M]. Beijing: China Democracy and Legal Publishing House, 2014. (in Chinese) 